\title{
Determination of Selected Heavy Metal Concentrations in an Oil Palm Plantation Soil
}

\author{
Wan Noni Afida Ab Manan, ${ }^{1 *}$ Fazrul Razman Sulaiman, ${ }^{1}$ Rubaiyah Alias ${ }^{1}$ \\ and Rusdin Laiman ${ }^{2}$ \\ ${ }^{1}$ Faculty of Applied Sciences, Universiti Teknologi MARA Pahang, \\ Bandar Tun Abdul Razak, Jengka, 26400, Pahang, Malaysia \\ ${ }^{2}$ Faculty of Applied Sciences, Universiti Teknologi MARA, \\ 40450, Shah Alam, Selangor, Malaysia \\ *Corresponding author: noniafida@gmail.com
}

Published online: 25 October 2018

To cite this article: Ab Manan, W. N. A. et al. (2018). Determination of selected heavy metal concentrations in an oil palm plantation soil. J. Phys. Sci., 29(Supp. 3), 63-70, https://doi. org/10.21315/jps2018.29.s3.8

To link to this article: https://doi.org/10.21315/jps2018.29.s3.8

\begin{abstract}
Heavy metals occur naturally in soil, but the agricultural, mining and industrial activities could enhance their concentration in soil. The application of chemical fertilisers in the agricultural soil can increase the level of heavy metals. This study was carried out in an oil palm plantation to identify presence of selected heavy metals in soil and estimate the pollution level due to presence of these compounds. The soil samples were collected in triplicates using a hand auger. The samples were then digested and the heavy metals were analysed using Inductively Coupled Plasma-Optical Emission Spectrometer (ICP-OES). Geo-accumulation index ( $\left.I_{\text {geo }}\right)$ was used to assess the degree of heavy metal contamination. Heavy metal concentration ranges were as follow: 0.76-2.00 mg kg-1 for Cu, 0.29-1.58 $\mathrm{mg} \mathrm{kg}^{-1}$ for zinc (Zn), 0.07-0.22 $\mathrm{mg} \mathrm{kg}^{-1}$ for lead (Pb) and 0.01-0.05 mg kg-1 for nickel (Ni). Copper (Cu) concentration was found to be higher than others. The accumulation of $\mathrm{Cu}$ and $\mathrm{Zn}$ in soil was possibly related to the application of chemical fertilisers. All samples showed $I_{\text {geo }}$ value less than 2, indicating that the soil was uncontaminated. This suggests that the application of chemical fertiliser is still under control. Nevertheless, a comprehensive metal analysis including arsenic (As) and cadmium $(C d)$, as well as the distribution pattern of metal in the agricultural soil is still required.
\end{abstract}

Keywords: Agricultural soil, chemical fertiliser, heavy metal concentration, geoaccumulation index, heavy metal 


\section{INTRODUCTION}

Soil pollution, which has been occurring in the last few decades, has become an environmental concern, especially in developed countries. ${ }^{1}$ Soil contains organic matter, mineral particles, water, air and living organisms. Contamination of soil by heavy metals is a main type of soil pollution, especially if it involves agricultural soil. In agricultural activities such as in oil palm plantation, a great amount of chemical products is used, either as fertilisers or pesticides. This application contributes to the increase of heavy metals such as cadmium $(\mathrm{Cd})$, lead $(\mathrm{Pb})$ and arsenic (As) in the soil. ${ }^{2}$ The application of fertilisers does not only serve for plant nutrients; it can also alter the bioavailability of heavy metals in soil. ${ }^{3}$ The nitrogen fertiliser application at oil palm plantation contributes to the release of nitrous oxide $\left(\mathrm{N}_{2} \mathrm{O}\right) .{ }^{4}$ Soil contaminated by heavy metals could contribute to the carcinogenic and non-carcinogenic effect to human and other living organisms. ${ }^{5}$

The excessive use of chemical fertilisers in agricultural activities have contributed to environmental problems especially in the soil. The abundance of chemical fertilisers can alter the soil properties such as $\mathrm{pH}$ and surface charge, or directly react with heavy metal ions in the soil. Other than that, excessive amount of fertilisers contributes negative impacts such as leaching, pollution of water resources as well as destruction of micro-organisms in fertile soil. ${ }^{6}$

It is important to note that increased heavy metal contents can directly affect the public health through food intake, direct ingestion and dermal contact, especially for children. ${ }^{7}$ It is necessary to determine the concentration of the metal uptake in agricultural soil. Thus, this study is carried out in a oil palm plantation area in Jengka 8, Pahang, Malaysia as a pilot study to determine the selected heavy metal concentrations.

\section{EXPERIMENTAL}

\subsection{Study Site}

Soil samples were collected around oil palm plantation which covered an area of 33.64 ha at Felda Jengka 8, Pahang (Figure 1). Felda Jengka or generally known as Jengka Triangle was first formed in 1967 and is located in the east coast state of Pahang, Malaysia. Most of the people residing in this area are fully involved in the agricultural activities especially related to rubber trees and oil palm plantation. A modern farming approach has been adopted, where various types of pesticides and chemical fertilisers are widely used. 


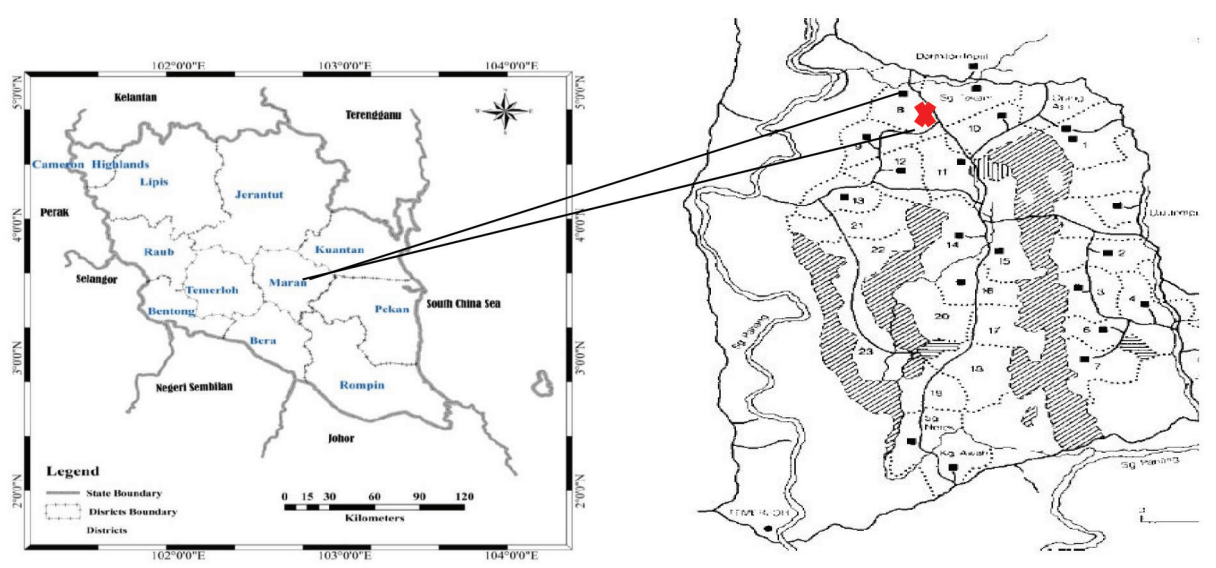

Figure 1: Sampling location in Felda Jengka 8, Pahang (source: Gabdo and Garba ${ }^{8}$ ).

\subsection{Sample Collection and Preparation}

Soil samples were collected from nine different points which were indicated as A, B, C, D, E, F, G, H and I. The soil samples were collected as triplicates to a depth of range $0-45 \mathrm{~cm}$ using a hand auger within $9 \mathrm{~m}$ radius between two oil palm trees. The schematic triangular method proposed by Mat Akhir et al. as shown in Figure 2 was implemented. ${ }^{4}$ All soil samples were collected during the sunny day and after application of fertilisers. Then, they were stored in a polyethylene bag. Control soil sample was collected from an undisturbed non-agricultural area, and used as a background value of the metal for this study.
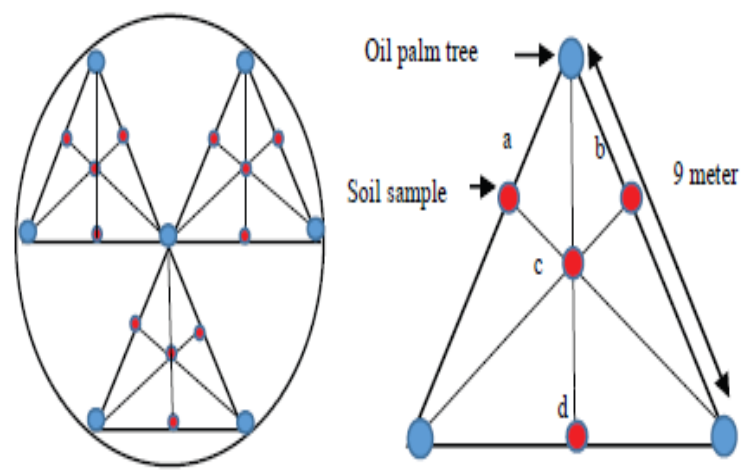

Figure 2: Schematic triangular sampling of soil modified from Mat Akhir et al. ${ }^{4}$

The soil samples were sieved with $2 \mathrm{~mm}$ sieve to remove leaves, roots and stones. The collected soil samples were dried at room temperature for three days. 
The samples were ground into fine particles using a mechanical grinder. Then, the samples were digested by wet digestion method. About $1.0 \mathrm{~g}$ of sample was weighed. The soil samples were digested with a mix of $6 \mathrm{ml}$ of nitric acid, $\mathrm{HNO}_{3}$ $(65 \%)$ and $2 \mathrm{ml}$ of hydrogen peroxide, $\mathrm{H}_{2} \mathrm{O}_{2}(30 \%)$. The mixture was heated on a hot plate at $130^{\circ} \mathrm{C}$ for $2 \mathrm{~h}$ until complete solubilisation. After that, the mixture was filtered through Whatman 42 filter paper. The filtered samples were diluted with deionised water until calibration mark by using $50 \mathrm{ml}$ volumetric flask. The soil samples were acidified with nitric acid and stored at $4^{\circ} \mathrm{C}$ in the refrigerator prior to analysis to minimise biological, chemical or physical changes that can occur between the time of collection and analysis. ${ }^{9}$

\subsection{Heavy Metal Analysis}

The heavy metal concentration of the solutions was determined by an ICP-OES device (Agilent Technologies 5100). The standard solution used for calibration was prepared by diluting a stock solution of $100 \mathrm{mg} \mathrm{l}^{-1}(\mathrm{Cu}, \mathrm{Zn}, \mathrm{Pb}$ and $\mathrm{Ni})$. The standard solutions with $0.5 \mathrm{ppm}, 1.5 \mathrm{ppm}, 2.5 \mathrm{ppm}, 3.5 \mathrm{ppm}$ and $4.5 \mathrm{ppm}$ were prepared. The soil samples were run simultaneously. The same procedure was also applied for the control soil. Quality assurance and quality control (QA/QC) is required to produce consistent and representative data. ${ }^{10,11}$ Three replications were performed for each sample. QA/QC for metals in agricultural soils was estimated by determining metal contents in the standard reference material as recommended by the World Health Organization (WHO).

\section{RESULTS AND DISCUSSION}

\subsection{Heavy Metal Concentrations in Analysed Soil Samples}

Four heavy metals concentrations $(\mathrm{Cu}, \mathrm{Zn}, \mathrm{Pb}$ and $\mathrm{Ni})$ were determined. Table 1 shows the concentration of heavy metal in soil samples in $\mathrm{mg} \mathrm{kg}^{-1}$. The concentration of $\mathrm{Cu}$ had the highest value for each point of soil samples as expected. The heavy metal concentration ranges for the studied metals were observed as follows: $0.76-2.00 \mathrm{mg} \mathrm{kg}^{-1}$ for $\mathrm{Cu}, 0.29-1.58 \mathrm{mg} \mathrm{kg}^{-1}$ for $\mathrm{Zn}, 0.07-0.22 \mathrm{mg} \mathrm{kg}^{-1}$ for $\mathrm{Pb}$ and $0.01-0.05 \mathrm{mg} \mathrm{kg}^{-1}$ for $\mathrm{Ni}$. The highest average $\mathrm{Cu}$ content in the soil for point $\mathrm{B}$ was $2.00 \mathrm{mg} \mathrm{kg}^{-1}$. The lowest $\mathrm{Cu}$ concentration was determined in control soil $\left(0.76 \mathrm{mg} \mathrm{kg}^{-1}\right)$. The highest concentration of $\mathrm{Zn}$ was found at point $\mathrm{B}$ soil $\left(1.58 \mathrm{mg} \mathrm{kg}^{-1}\right)$ as seen in Table 1 . The average concentration of $\mathrm{Pb}$ in soil was higher at point B was $0.22 \mathrm{mg} \mathrm{kg}^{-1}$ compared with other points. All soil samples had a very low concentration of Ni. The soil that contained the highest amount of 
$\mathrm{Ni}$ was at point $\mathrm{B}$, at $0.05 \mathrm{mg} \mathrm{kg}^{-1}$. This suggests that point $\mathrm{B}$ is contaminated by heavy metal compared to other points.

Table 1: Concentration of heavy metal in soil samples in $\mathrm{mg} \mathrm{kg}^{-1}$ (mean $\left.\pm \mathrm{SD}\right)$.

\begin{tabular}{lcccc}
\hline Soil samples & $\mathrm{Cu}$ & $\mathrm{Zn}$ & $\mathrm{Pb}$ & $\mathrm{Ni}$ \\
\hline Point A & $0.91 \pm 0.13$ & $0.46 \pm 0.19$ & $0.12 \pm 0.03$ & $0.02 \pm 0.007$ \\
Point B & $2.00 \pm 0.19$ & $1.58 \pm 0.73$ & $0.22 \pm 0.04$ & $0.05 \pm \mathrm{BDL}$ \\
Point C & $1.18 \pm 0.22$ & $0.55 \pm 0.32$ & $0.09 \pm 0.02$ & $0.02 \pm 0.007$ \\
Point D & $1.53 \pm 0.66$ & $0.90 \pm 0.37$ & $0.12 \pm 0.06$ & $0.03 \pm 0.02$ \\
Point E & $1.87 \pm 0.23$ & $0.85 \pm 0.49$ & $0.13 \pm 0.01$ & $0.03 \pm 0.007$ \\
Point F & $1.37 \pm 0.55$ & $0.53 \pm 0.21$ & $0.09 \pm 0.04$ & $0.04 \pm 0.02$ \\
Point G & $1.26 \pm 0.24$ & $0.51 \pm 0.03$ & $0.09 \pm 0.02$ & $0.03 \pm 0.02$ \\
Point H & $1.30 \pm 0.46$ & $0.76 \pm 0.25$ & $0.08 \pm 0.03$ & $0.05 \pm 0.007$ \\
Point I Control & $1.29 \pm 0.23$ & $0.73 \pm 0.08$ & $0.12 \pm 0.02$ & $0.04 \pm 0.007$ \\
& $0.76 \pm 0.34$ & $0.29 \pm 0.05$ & $0.07 \pm 0.04$ & $0.01 \pm \mathrm{BDL}$ \\
\hline
\end{tabular}

Notes: $B D L=$ below detectable limit, $S D=$ standard deviation. Data represented the mean of three replicates.

The highest concentration at point B was related to anthropogenic sources. Besides the application of chemical fertilisers at point B, the location itself influenced the concentration of heavy metals. Point B was situated near a paved road. The combustion process from vehicles, the layer of road degradation and the particles from the road surface contributed to released pollutants to the surrounding. ${ }^{12}$ Agricultural activities such as the application of chemical fertilisers will increase the metal concentrations in soil. ${ }^{10}$ The main composition for chemical fertilisers were macronutrients and micronutrients. Nitrogen, phosphorus and potassium are examples of macronutrient. Micronutrients refer to sulphates or oxides of zinc, copper and manganese. ${ }^{13}$ The use of copper sulphate $\left(\mathrm{CuSO}_{4}\right)$ and cupric oxide $(\mathrm{CuO})$ to increase the growth process probably enhance the $\mathrm{Cu}$ concentration. ${ }^{1}$ Other micronutrients include zinc oxides $(\mathrm{ZnO})$ and zinc sulfate $\left(\mathrm{ZnSO}_{4}\right)$ that contain $70 \%-80 \%$ zinc and $22 \%-36 \%$ sulphate. ${ }^{14}$

\subsection{Geo Accumulation Index $\left(\mathrm{I}_{\text {geo }}\right)$}

Geo accumulation index $\left(\mathrm{I}_{\mathrm{geo}}\right)$ was used in this study to determine the degree of heavy metal contamination in the soils at the oil palm plantation area. ${ }^{15}$ The control soil was used as a background value for $\mathrm{I}_{\text {geo }}$ calculation. The $\mathrm{I}_{\mathrm{geo}}$ of metal in the soil can be calculated using Equation 1:

$$
\mathrm{I}_{\mathrm{geo}}=\log _{2}\left(\mathrm{C}_{\mathrm{n}} / 1.5 \mathrm{~B}_{\mathrm{n}}\right)
$$


where $C_{n}$ is the measured concentration of heavy metal in the soil, and $B_{n}$ the geochemical background value in average shale of an element.

Table 2 represents the classification for $I_{\text {geo }}$ value. There are six classes for $I_{\text {geo }}$ encompassing a range of classifications, from uncontaminated to very highly contaminated. ${ }^{15}$

Table 2: Classification for $\mathrm{I}_{\mathrm{geo}}$ values.

\begin{tabular}{lcl}
\hline Igeo value & Class & Terminology \\
\hline$\leq 0$ & 0 & Uncontaminated \\
$0-1$ & 1 & Uncontaminated to fairly contaminated \\
$1-2$ & 2 & Fairly contaminated \\
$2-3$ & 3 & Fairly to high contaminated \\
$3-4$ & 4 & Highly contaminated \\
$4-5$ & 5 & Highly to very highly contaminated \\
$>6$ & 6 & Very highly contaminated \\
\hline
\end{tabular}

Table 3 shows that all sampling points have low $\mathrm{I}_{\text {geo }}$ values for $\mathrm{Cu}, \mathrm{Zn}, \mathrm{Pb}$ and $\mathrm{Ni}$ in oil palm plantation soil. This indicates that the oil palm plantation soil was uncontaminated to moderately contaminated by these four metals. Point B shows the highest $\mathrm{I}_{\text {geo }}$ values for heavy metals. The $\mathrm{I}_{\text {geo }}$ values for $\mathrm{Zn}, \mathrm{Ni}, \mathrm{Pb}$ and $\mathrm{Cu}$ at point $\mathrm{B}$ were $1.09,1.00,0.63$ and 0.53 , respectively. The excessive application of fertilisers around point $\mathrm{B}$ perhaps contributed to the accumulation of heavy metal in soil. However, the soil samples at point A, C, D, E, F, G, H and I had low Igeo values for these four metals.

Table 3: $I_{\text {geo }}$ values for selected metals in soil samples.

\begin{tabular}{lllll}
\hline Soil samples & $\mathrm{Cu}$ & $\mathrm{Zn}$ & $\mathrm{Pb}$ & $\mathrm{Ni}$ \\
\hline Point A & 0.24 & 0.32 & 0.34 & 0.40 \\
Point B & 0.53 & 1.09 & 0.63 & 1.00 \\
Point C & 0.31 & 0.37 & 0.27 & 0.40 \\
Point D & 0.40 & 0.62 & 0.34 & 0.60 \\
Point E & 0.49 & 0.59 & 0.37 & 0.60 \\
Point F & 0.36 & 0.37 & 0.26 & 0.80 \\
Point G & 0.33 & 0.35 & 0.25 & 0.60 \\
Point H & 0.34 & 0.53 & 0.23 & 0.94 \\
Point I & 0.34 & 0.51 & 0.34 & 0.74 \\
\hline
\end{tabular}




\section{CONCLUSION}

From this study, the soil from the oil palm plantation does not indicate serious pollution problem. The concentration of heavy metals in soil was mainly from natural sources such as windblown dust and derivative of rock and soil. However, the application of chemical fertiliser in the oil palm soil will increase the level of heavy metal, unless it is controlled. $\mathrm{Cu}$ concentration in soil samples was dominant and perhaps related to the application of chemical fertiliser. The amount of chemical fertilisers that are applied to the oil palm should be controlled to avoid soil toxicity. Further study should focus on the evaluation of toxic metals for example $\mathrm{As}$ and $\mathrm{Cd}$ in order to determine the possible contamination and toxicity level in the agricultural soil.

\section{ACKNOWLEDGEMENTS}

The corresponding author wishes to acknowledge Universiti Teknologi MARA (UiTM), Malaysia for funding the work through research grant iRAGS 600-RMI/ iRAGS 5/3 (16/2015). The author would like to acknowledge and appreciate the other members of research grant on contribution and support to this study.

\section{REFERENCES}

1. Mico, C., Retacala, L. \& Sanchez, J. (2006). Assessing heavy metal sources in agriculture soil of a European Mediterranean area by multivariate analysis. Chemosph., 65, 863-887, https://doi.org/10.1016/j. chemosphere.2006.03.016.

2. Atafar, Z. et al. (2010). Effect of fertilizer application on soil heavy metal concentration. Environ. Monit. Assess., 160, 83-89, https://doi.org/10.1007/ s10661-008-0659-x.

3. Zeng, F. et al. (2011). The influence of $\mathrm{pH}$ and organic matter content in paddy soil on heavy metal availability and their uptake by rice plants. Environ. Pollut., 159, 84-91, https://doi.org/10.1016/j.envpol.2010.09.019.

4. Mat Akhir, N. I. et al. (2015). Impact of nitrogen fertilizer application on nitrous oxide emission in oil palm plantation. Proced. Environ. Sci., 30, 315-319, https://doi.org/10.1016/j.proenv.2015.10.056.

5. Yu, L. et al. (2008). Heavy metal contamination and source in arid agricultural soil in central Gansu Province, China. Environ. Sci., 20, 607-612, https:// doi.org/10.1016/S1001-0742(08)62101-4. 
6. Li, Z. et al. (2014). A review of soil heavy metal pollution from mines in China: Pollution and health risk assessment. Sci. Total Environ., 468-469, 843-853, https://doi.org/10.1016/j.scitotenv.2013.08.090.

7. Huang, S. S. et al. (2007). Survey of heavy metal pollution and assessment of agricultural soil in Yangzhong district, Jiangsu Province, China. Chemosph., 67, 2148-2155, https://doi.org/10.1016/j.chemosphere.2006.12.043.

8. Gabdo, H. T. \& Garba, N. N. (2017). Terrestrial gamma radiation absorption and the effect of its inhalation to the internal organs of human body: A case study of Pahang State Malaysia. Bayero J. Pure App. Sci., 10(1), 84-88, https://doi.org/10.4314/bajopas.v10i1.17S.

9. U.S. Environmental Protection Agency. (2002). Methods for the determination of total organic carbon (TOC) in soils and sediments. USEPA NCEA-C-1282 (EMASC-001), 23.

10. Sulaiman, F. R. et al. (2016). Preliminary assessment of selected metals in agricultural soils in Jengka, Pahang, Malaysia. Environ. Earth Sci., 75(3), 223, https://doi.org/10.1007/s12665-015-4926-1.

11. Praveena, S. M. \& Aris, A. Z. (2012). A baseline study of tropical coastal water quality in Port Dickson, Straits of Malacca, Malaysia. Mar. Pollut. Bull., 67, 196-199, https://doi.org/10.1016/j.marpolbul.2012.11.037.

12. Bohemen, H. D. V. \& Laak, W. H. J. V. D. (2003). The influence of road infrastructure and traffic on soil, water and air quality. Environ. Manage., 31, 50-68, https://doi.org/10.1007/s00267-002-2802-8.

13. Li, K., Xing, B. \& Torello, W. A. (2005). Effect of organic fertilizers derived dissolved organic matter on pesticide sorption and leaching. Environ. Pollut., 134, 187-194, https://doi.org/10.1016/j.envpol.2004.08.011.

14. Jiang, W. et al. (2014). Evaluation of potential effects of soil available phosphorus on soil arsenic availability and paddy rice inorganic arsenic content. Environ. Pollut., 188, 159-165, https://doi.org/10.1016/j. envpol.2014.02.014.

15. Shafie, N. A. et al. (2013). Application of geoaccumulation index and enrichment factors on the assessment of heavy metal pollution in the sediments. J. Environ. Sci. Health A., 48, 182-190, https://doi.org/10.1080/ 10934529.2012.717810. 